Revista Brasil. Bot., V.25, n.2, p.221-228, jun. 2002

\title{
Caracterização morfo-anatômica da folha e do caule de Brachiaria brizantha (Hochst. ex A. Rich.) Stapf e B. humidicola (Rendle) Schweick. (Poaceae)
}

\author{
CLÁUDIO J.F.A. BRITO ${ }^{1,3}$ e ROBERTO A. RODELLA ${ }^{2}$
}

(recebido: 11 de julho de 2001; aceito: 27 de março de 2002)

\begin{abstract}
Leaf and stem morpho-anatomical characterization of Brachiaria brizantha (Hochst. ex A. Rich.) Stapf and B. humidicola (Rendle) Schweick. (Poaceae)). The morpho-anatomy of the leaf and stem of B. brizantha and B. humidicola were studied at three plant stratums. The difference among the species and the different stratums were investigated in order to justify the different intensities of consumption that occurs with plant aging. The experiment was carried out in a greenhouse and on plants cultivated in plastic vessels with sterilized sand, receiving nutritive mineral solution. After 70 days, the median leaf of each stratum was collected and divided into limbo and leaf sheath. The same was done to the stem. For the morphological study the total plant height, number of leaves, nodes and sprouts, length and width of blades and sheaths and length and diameter of internodes were measured. For purposes of anatomical characterization the samples were fixed in FAA, embedded in GMA, sectioned in microtome e stained with basic fucsin and Astra blue. The morpho-anatomical studies indicated some parameters that can interfere on tissue digestibility. The species presented different morphology, with shorter and narrower limbo measurements, thereby may affect the accessibility to lower leaves and interfering on the forage consumption. The stem was the fraction with the most variation between species, and showing in $B$. brizantha a larger stem diameter and thicker culm wall, which make the stem more resistant to apprehension, suggesting a larger number of vascular bundles and, consequently, a high percentage of lignified tissues. Secretory structures were identified below the trichome base cells in the leaf sheaths of $B$. brizantha, probably as secretory cavities, quite rare in Poaceae and there are no studies about its interference on digestibility and consumption.
\end{abstract}

RESUMO - (Caracterização morfo-anatômica da folha e do caule de Brachiaria brizantha (Hochst. ex A. Rich.) Stapf e B. humidicola (Rendle) Schweick. (Poaceae)). Neste trabalho, caracterizou-se a morfo-anatomia do caule e da folha de Brachiaria brizantha e $B$. humidicola, em três estratos, objetivando diferenciar tais estratos e espécies, bem como justificar, com estes parâmetros, a diferença de consumo que ocorre nessas espécies com o envelhecimento da planta. O experimento foi conduzido em casa de vegetação, utilizando-se vasos plásticos com areia esterilizada e recebendo solução nutritiva. Aos 70 dias após o corte de uniformização, cada planta foi dividida em três partes (estratos), coletando-se a folha mediana de cada estrato, separando-a em limbo e bainha foliar, e também o entrenó recoberto pela referida bainha. Para o estudo morfológico, foram mensurados a altura total das plantas, número total de folhas, nós e perfilhos, comprimento e largura da lâmina e da bainha foliar, comprimento e diâmetro do entrenó. Para a caracterização anatômica, as amostras foram fixadas em FAA, emblocadas em GMA, seccionadas em micrótomo e coradas com fucsina básica e azul de Astra. Os estudos morfo-anatômicos indicaram parâmetros que podem interferir na digestibilidade de seus tecidos. Verificou-se que as espécies apresentaram diferenças quanto aos aspectos morfológicos, destacando em B. humidicola menores valores de comprimento e largura do limbo, o que pode dificultar a seleção das folhas inferiores, interferindo no consumo dessa forrageira. Constatou-se, também, que o caule foi a fração que mais variou entre as espécies, apresentando $B$. brizantha diâmetro do entrenó maior e "parede" do colmo mais espessa, o que, além de tornar o caule mais resistente à apreensão, sugere maior número de feixes vasculares e, conseqüentemente, porcentagem de tecidos lignificados. Observaram-se estruturas secretoras na base dos tricomas da bainha foliar de B. brizantha, sugerindo cavidades secretoras, bastante raras na família Poaceae, não havendo estudos de sua interferência no consumo e digestibilidade.

Key words - anatomy, Brachiaria, grasses, forages, morphology

\section{Introdução}

O gênero Brachiaria (Trinius) Grisebach é constituído por plantas herbáceas, perenes ou anuais,

1. Centro Universitário Campos de Andrade - Uniandrade. Caixa Postal 623, 80011-970 Curitiba, PR, Brasil.

2. Universidade Estadual Paulista, Instituto de Biociências, Departamento de Botânica, Caixa Postal 510, 18618-000 Botucatu, SP, Brasil.

3. Autor para correspondência: cjbrito@ hotmail.com eretas ou decumbentes. Cerca de 100 espécies são naturais de todas as regiões tropicais, mais especialmente da África (Pupo 1980).

Brachiaria brizantha (Hochst. ex A. Rich.) Stapf é perene, apresentando rizomas curtos, colmos normalmente eretos, sem ramos ou pouco ramificados, com 4-6 nós, não perfilhando intensamente nem emitindo raízes adventícias nos nós. As folhas são glabras até pubescentes, com bainhas roliças e pouco persistentes; as lâminas foliares são agudas, com 
5-30 $\mathrm{cm}$ de comprimento e 0,6-1,6 $\mathrm{cm}$ de largura, cartilagíneo-marginadas, ciliadas (Smith et al. 1982). Quando bastante desenvolvida, forma touceiras que chegam a atingir $2 \mathrm{~m}$ de altura, por isso, alguns autores, como Salerno et al. (1990), consideram esta espécie cespitosa. Dentre as braquiárias, é considerada a mais resistente à seca e ao frio, vegetando tanto em solos úmidos quanto secos, não exigindo muita fertilidade, porém, mais exigente que $B$. humidicola (Salerno et al. 1990, Alcântara \& Bufarah 1992).

Brachiaria humidicola (Rendle) Schweick. também é perene, ereta (Smith et al. 1982, Alcântara \& Bufarah 1992) ou decumbente (Salerno et al. 1990), rizomatosa (Alcântara \& Bufarah 1992) ou estolonífera (Pupo 1980, Smith et al. 1982, Salerno et al. 1990). Os colmos são solitários, geniculados na base e a partir da ramificação, ascendentes e delgados. Folhas com bainhas bem mais curtas que os entrenós; lâminas foliares ascendentes, linear-lanceoladas, subagudas, com 6-11 cm de comprimento e 1,0-1,2 cm de largura, com margens espessadas e miudamente serrilhadas (Smith et al. 1982). É pouco exigente quanto ao solo, vegeta bem em locais úmidos ou secos, sendo resistente à geada. Tem sido largamente utilizada para formação de pastagens nas mais diferentes regiões do país, sendo promissora para a região amazônica (Pupo 1980, Alcântara \& Bufarah 1992).

Brachiaria brizantha e B. humidicola são forrageiras tropicais, as quais possuem via fotossintética $\mathrm{C}_{4}$, associada à anatomia Kranz. Esta anatomia apresenta feixes vasculares circundados por células mesofílicas em disposição radiada, e mais internamente, uma ou duas camadas de células denominadas de bainha parenquimática e bainha mestomática, respectivamente (Oliveira et al. 1973).

Metcalfe (1960) descreveu algumas características da superfície epidérmica e da anatomia de algumas espécies do gênero Brachiaria, porém não incluindo as duas espécies em estudo. Posteriormente, Rodella et al. (1982) avaliaram quantitativamente os diferentes tecidos presentes nas folhas de B. brizantha e $B$. mutica, em três níveis de inserção no caule.

Os objetivos deste trabalho constituíram-se em caracterizar a morfologia de Brachiaria brizantha e $B$. humidicola, bem como caracterizá-las estruturalmente em três diferentes estratos da planta, procurando-se observar caracteres morfo-anatômicos que possam interferir na digestibilidade de seus tecidos com relação à degradação ruminal em bovinos.

\section{Material e métodos}

O material botânico utilizado foi representado por folhas (lâminas e bainhas foliares) e caules de Brachiaria brizantha (Hochst. ex A. Rich.) Stapf e de B. humidicola (Rendle) Schweick.

Para condução do ensaio, as mudas foram plantadas em vasos plásticos, providos de areia esterilizada e dispostas em casa de vegetação, recebendo solução nutritiva por gotejamento automático, a qual continha os macro e microelementos minerais necessários para o seu adequado desenvolvimento. O experimento foi desenvolvido na Empresa Catarinense de Pesquisa e Extensão Agropecuária - EPAGRI S.A., Estação Experimental de Itajaí, Santa Catarina, Brasil (26054'28' S e 48 39'43"' W, 5 m.s.m.).

Aos 70 dias após o corte de uniformização das parcelas, coletaram-se indivíduos pertencentes às duas espécies. Cada planta foi dividida em três partes (terços apical, mediano e basal), considerando-se como comprimento total da planta o primeiro (basal) e o último (apical) nó visível no caule. De cada terço selecionado (estrato) foi coletada a folha que ocupava a região mediana, retirando-se dela a porção média da lâmina (limbo) e da bainha foliar, bem como a porção média do entrenó recoberto pela bainha foliar amostrada.

$\mathrm{O}$ estudo morfo-anatômico foi desenvolvido junto ao Laboratório de Anatomia Vegetal, do Departamento de Botânica, do Instituto de Biociências de Botucatu, UNESP.

As amostras destinadas ao estudo anatômico foram imediatamente fixadas em FAA 50, por aproximadamente 48 horas, e conservadas em etanol $70 \%$, de acordo com a metodologia de Johansen (1940). Posteriormente, foram desidratadas em série etílica e emblocadas em glicol metacrilato (GMA) JB-4 (Polysciences, Inc.), seguindo-se as recomendações do fabricante e de Feder \& O'Brien (1968). Em seguida, foram seccionadas transversalmente em micrótomo rotatório Leica RM-2145, distendidas em água e coradas com solução aquosa de fucsina básica $0,0125 \%$ e azul de Astra 1,0\% (Alves de Brito \& Alquini 1996). Uma vez efetuada a dupla coloração, as lâminas foram lavadas em água corrente, secas em estufa a $40{ }^{\circ} \mathrm{C}$ e submetidas à montagem convencional e recobertas com lamínula. Após a confecção do laminário, as secções foram fotomicrografadas em equipamento Zeiss-Axiolab. Considerou-se como a espessura da "parede" do colmo a medida entre a epiderme e o início da cavidade medular, realizando-se quatro medidas por repetição, com auxílio de microscópio de projeção Zeiss.

Para o estudo morfométrico, foram mensurados, com auxílio de trena e paquímetro, a altura total das plantas, número total de folhas, nós e perfilhos, comprimento e largura da lâmina e da bainha foliar, comprimento e diâmetro do entrenó.

Foram utilizadas 25 repetições para os dados morfológicos e cinco repetições para os dados de espessura da "parede" do colmo, e as médias submetidas à análise de variância, com comparação de médias pelo teste de Tukey ao nível de $5 \%$ de probabilidade. 


\section{Resultados e Discussão}

Morfometria - Na tabela 1 encontram-se os resultados referentes aos aspectos morfológicos das espécies em estudo. Verifica-se que $B$. brizantha apresenta porte mais elevado, com medidas semelhantes às descritas por Smith et al. (1982), mesmo número de folhas, menor número total de nós e menor quantidade de perfilhos, quando comparada à B. humidicola. A B. brizantha também apresenta maior comprimento médio do limbo e da bainha, bem como limbos mais largos e maior diâmetro de entrenós; entretanto, para o comprimento do entrenó não apresentou diferença significativa.

Comparando-se esses dados, com os descritos por Smith et al. (1982), constatou-se que, neste experimento, ambas as espécies possuem lâminas foliares mais compridas e apenas $B$. brizantha possui lâminas mais largas e número semelhante de nós.

Tabela 1. Morfometria de Brachiaria brizantha e B. humidicola.

\begin{tabular}{lrc}
\hline & B. brizantha & B. humidicola \\
\hline Altura da planta $(\mathrm{cm})$ & $149,92 \mathrm{a}$ & $117,92 \mathrm{~b}$ \\
N. de folhas & $5,72 \mathrm{a}$ & $5,40 \mathrm{a}$ \\
N. de nós & $5,04 \mathrm{~b}$ & $6,00 \mathrm{a}$ \\
N. de perfilhos & $0,16 \mathrm{~b}$ & $1,00 \mathrm{a}$ \\
\hline
\end{tabular}

Letras iguais maiúsculas na coluna, dentro de cada fração e minúsculas na linha, não diferem significativamente $(\mathrm{p}>0,05)$, segundo o teste de Tukey.

Observando-se a tabela 2, nota-se que em $B$. brizantha os limbos dos estratos apical e mediano possuem comprimentos semelhantes, enquanto em $B$. humidicola, o limbo apical é menor que o do estrato mediano. Tal aspecto, associado à largura do limbo, que é bem maior em $B$. brizantha, confere à $B$. humidicola um ápice da planta com folhas mais pontiagudas (comprimento e largura menores). Isso poderia afetar o consumo dessa forrageira por bovinos, já que dificultaria o acesso às folhas de estratos inferiores de inserção, quando da apreensão das mesmas.

Anatomia do caule - O caule de ambas as espécies é do tipo colmo, apresentando medula oca (figuras 1,2), com contorno externo ovalado, côncavo em um dos lados, assim como descrito para B. reptans (Metcalfe 1960). Em secção transversal a epiderme apresenta células tetraédricas, com paredes lignificadas e, principalmente, as paredes periclinal externa e as anticlinais, são
Tabela 2. Morfometria das frações limbo, bainha foliar e caule (entrenó) de Brachiaria brizanthae B. humidicola, em três estratos da planta.

\begin{tabular}{|c|c|c|c|}
\hline Fração e Estrato & B. brizantha & B. humidicola & Média (s) \\
\hline & \multicolumn{3}{|c|}{ Comprimento $(\mathrm{cm})$} \\
\hline Limbo Apical & 54,56 Аа & $19,88 \mathrm{Bb}$ & 37,22 \\
\hline Limbo Mediano & $55,96 \mathrm{Aa}$ & $25,36 \mathrm{Ab}$ & 40,66 \\
\hline Limbo Basal & $37,04 \mathrm{Ba}$ & $17,20 \mathrm{Bb}$ & 27,12 \\
\hline Média (e) & 49,19 & 20,81 & \\
\hline Bainha Apical & $15,58 \mathrm{Bb}$ & 14,92 Аa & 15,25 \\
\hline Bainha Mediano & $16,72 \mathrm{ABa}$ & $11,84 \mathrm{Bb}$ & 14,28 \\
\hline Bainha Basal & $17,62 \mathrm{Aa}$ & $10,26 \mathrm{Bb}$ & 13,94 \\
\hline Média (e) & 16,64 & 12,34 & \\
\hline Entrenó Apical & $17,33 \mathrm{ABb}$ & $22,12 \mathrm{Aa}$ & 19,73 \\
\hline Entrenó Mediano & $20,74 \mathrm{Aa}$ & $15,14 \mathrm{Bb}$ & 17,94 \\
\hline Entrenó Basal & $16,08 \mathrm{Ba}$ & $11,86 \mathrm{Bb}$ & 13,97 \\
\hline \multirow[t]{2}{*}{ Média (e) } & 18,05 & 16,37 & \\
\hline & \multicolumn{3}{|c|}{ Largura $(\mathrm{cm})$} \\
\hline Limbo Apical & $1,96 \mathrm{Aa}$ & $0,76 \mathrm{ABb}$ & 1,36 \\
\hline Limbo Mediano & $1,90 \mathrm{Aa}$ & $0,86 \mathrm{Ab}$ & 1,38 \\
\hline Limbo Basal & $1,32 \mathrm{Ba}$ & $0,69 \mathrm{Bb}$ & 1,01 \\
\hline \multirow[t]{2}{*}{ Média (e) } & 1,73 & 0,77 & \\
\hline & \multicolumn{3}{|c|}{ Diâmetro (cm) } \\
\hline Entrenó Apical & $0,35 \mathrm{Aa}$ & $0,19 \mathrm{Bb}$ & 0,27 \\
\hline Entrenó Mediano & $0,35 \mathrm{Aa}$ & $0,22 \mathrm{Ab}$ & 0,29 \\
\hline Entrenó Basal & $0,34 \mathrm{Aa}$ & $0,21 \mathrm{ABb}$ & 0,28 \\
\hline \multirow[t]{2}{*}{ Média (e) } & 0,35 & 0,21 & \\
\hline & \multicolumn{3}{|c|}{ Espessura da "parede" do colmo $(\mathrm{cm})$} \\
\hline Entrenó Apical & 0,12 & 0,06 & $0,09 \mathrm{~A}$ \\
\hline Entrenó Mediano & 0,11 & 0,05 & $0,08 \mathrm{~A}$ \\
\hline Entrenó Basal & 0,12 & 0,04 & $0,08 \mathrm{~A}$ \\
\hline Média (e) & & $0,12 \mathrm{a}$ & $0,05 \mathrm{~b}$ \\
\hline
\end{tabular}

(s) - estrato; (e) - espécie

Letras iguais maiúsculas na coluna, dentro de cada fração e minúsculas na linha, não diferem significativamente $(\mathrm{p}>0,05)$, segundo o teste de Tukey.

recobertas por uma cutícula pronunciada (figuras 3,4 ), assim como descrito para $B$. radicans por Martire \& Caldas (1986).

Os feixes vasculares do tipo colateral fechado são poligonais ou angulosos (Metcalfe 1960), estando o floema voltado para a periferia do caule e o xilema em oposição (figuras 3,4), apresentando-se em três tamanhos distintos: pequeno, médio e grande porte. Os feixes estão envoltos por uma bainha esclerenquimática (figura 3), da mesma forma como descrito por Hayward (1953) e Esau (1972). No xilema do caule, em adição 

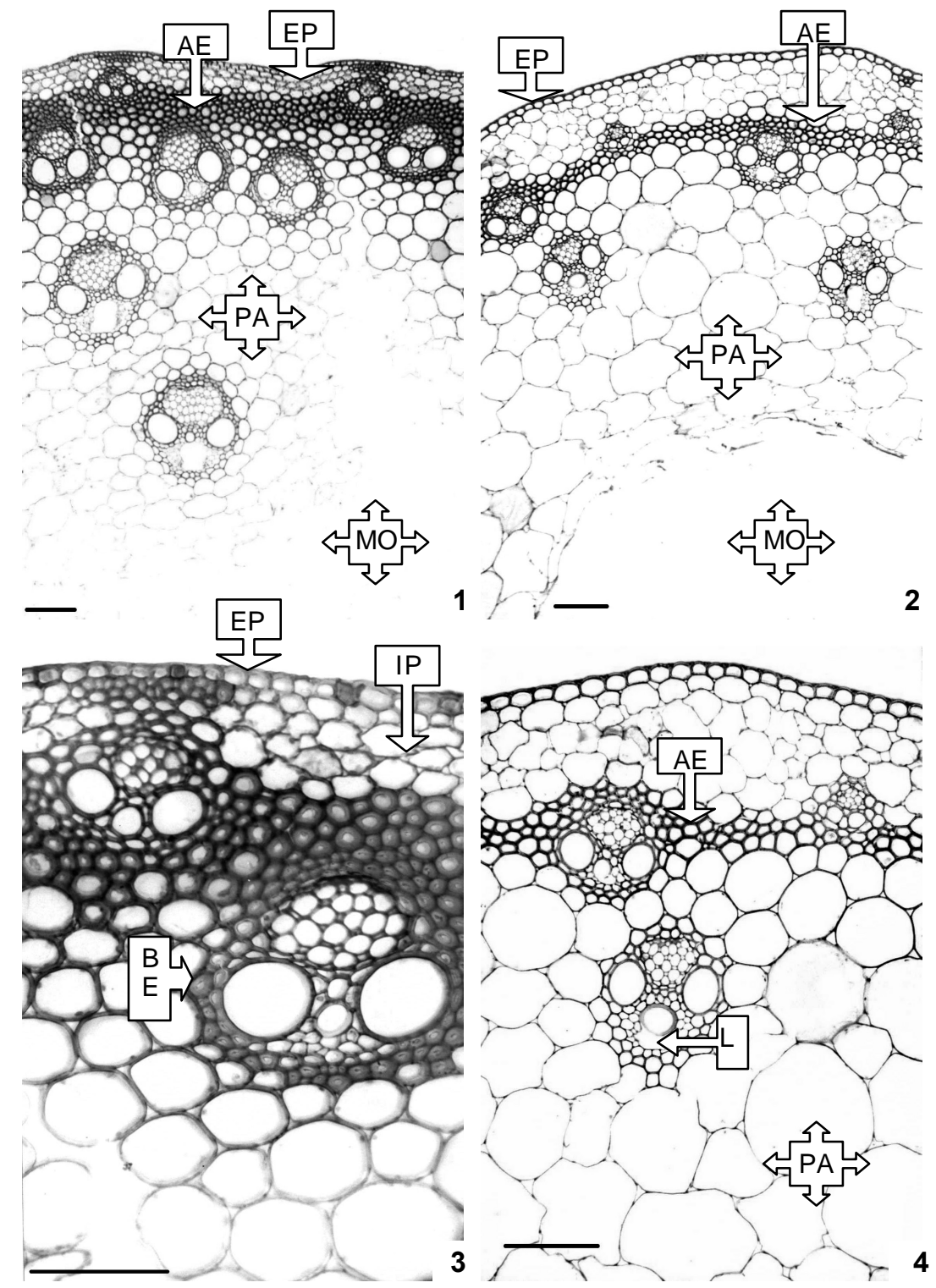

Figuras 1-4. Secções transversais do caule do estrato mediano de Brachiaria. 1, 3- B. brizantha. 2, 4 - B. humidicola. Barra $=180 \mu \mathrm{m}(1,2), 67 \mu \mathrm{m}(3)$ e $90 \mu \mathrm{m}$ (4). AE- anel esclerenquimático; $\mathrm{BE}=$ bainha esclerenquimática; $\mathrm{EP}=$ epiderme; $\mathrm{IP}=$ "ilhas" de clorênquima; $\mathrm{L}=$ lacuna; $\mathrm{MO}=$ medula oca; $\mathrm{PA}=$ parênquima.

aos elementos traqueais, geralmente existe uma grande proporção de parênquima xilemático e de tecido mecânico na forma de fibras xilemáticas, estando de acordo com a descrição feita por Mauseth (1995). Quando os feixes completam a sua diferenciação, o parênquima que rodeia o protoxilema sofre uma lise parcial, formando uma lacuna (figura 4). Os feixes vasculares estão irregularmente dispersos no parênquima fundamental (figuras 1,2), sendo esta distribuição denominada atactostélica, segundo padrão típico da Classe Liliopsida (Monocotiledôneas), citado por Esau (1972, 1974), Fahn (1974) e Mauseth (1988).

Encontra-se presente também o parênquima clorofiliano sub-epidérmico, composto de 4-6 camadas de células, de contorno poliédrico (figura 3), onde se observam feixes vasculares de pequeno porte. Em $B$. brizantha esses feixes são um pouco maiores e estão mais próximos à epiderme, fazendo com que o clorênquima forme "ilhas" entre os feixes vasculares, a epiderme e o anel esclerenquimático (figuras 1, 3).

Logo abaixo do clorênquima ocorre um anel esclerenquimático, com 2-5 camadas de células em B. humidicola (figuras 2, 4) e 6-10 em B. brizantha (figuras 1,3). Muitos feixes de pequeno e médio porte estão incluídos nesse anel, onde a bainha esclerenquimática dos feixes se mistura ao esclerênquima, da 
mesma forma como observaram Martire \& Caldas (1986).

Internamente ao anel esclerenquimático ocorre o parênquima fundamental, onde estão dispostos os feixes vasculares de grande porte, os quais possuem uma bainha esclerenquimática bastante reduzida. As células parenquimáticas possuem forma circular a poliédrica, com parede delgada e formam grandes espaços intercelulares. Aquelas células próximas à medula estão parcialmente destruídas, uma vez que a medula formase pela lise dessas células (figuras 1,2).

A "parede" do colmo da $B$. brizantha é mais espessa do que em $B$. humidicola, porém entre os estratos estudados não houve diferença significativa (tabela 1). Em $B$. brizantha, a maior espessura da "parede" do colmo está relacionada à ocorrência do maior diâmetro do entrenó (tabela 1), o que, conseqüentemente, pode acarretar uma maior quantidade de feixes vasculares.

Observou-se que o caule foi a fração que mais variou entre as espécies, e $B$. brizantha apresentou o diâmetro do entrenó maior e a "parede" do colmo mais espessa, o que, além de tornar o caule mais resistente à apreensão, sugere maior número de feixes vasculares e, conseqüentemente, maior porcentagem de tecidos lignificados.

Anatomia da bainha foliar - A bainha foliar de Brachiaria apresenta, em secção transversal, aspecto semicircular, onde as margens ficam parcialmente sobrepostas, envolvendo totalmente o caule (figura 8). Como padrão entre as espécies da família Poaceae, as lâminas e bainhas foliares apresentam venação paralela. A secção transversal da bainha foliar não revelou a presença de uma quilha, como na lâmina foliar, porém a bainha apresenta a região central alargada (figura 8), conforme descreveu Milby (1971).

Em secção transversal, as células epidérmicas da face adaxial, que estão em contato com o caule, apresentam-se achatadas, com formato retangular (figuras 5,6). Nessa face não foram observados tricomas ou estômatos. Logo abaixo da epiderme, em oposição aos feixes vasculares, existe uma pequena calota esclerenquimática, geralmente constituída por somente uma ou duas camadas de células (figuras 5,6).

No mesofilo, o parênquima clorofiliano apresenta células poliédricas, grandes, de paredes delgadas, que aumentam de tamanho à medida que se aproximam da região central (figuras 5-7).

Os feixes vasculares são de contorno poligonal (médio e grande porte) a circular (pequeno porte) e encontram-se próximos à face abaxial (figuras 5, 6). Nos feixes de médio e grande porte, ocorre uma extensão de bainha de feixe, bastante pronunciada e lignificada, que alcança a epiderme da face abaxial (figuras 5-7), assim como também descreveram Buvat (1989) e Alves de Brito et al. (1997). Nos feixes de pequeno porte, na face abaxial, há apenas uma calota esclerenquimática sub-epidérmica (figura 6).

Em B. humidicola ocorre uma bainha parenquimática envolvendo totalmente os feixes vasculares, como observado na lâmina foliar, caracterizando também a presença de anatomia Kranz na bainha foliar (figura 6). Já em $B$. brizantha essa bainha envolve apenas alguns feixes de pequeno porte, sendo que nos demais feixes está reduzida a poucas células, que não chegam a circundar totalmente o feixe (figura 5) e com poucos ou nenhum cloroplastídios, em disposição centrífuga, o que caracteriza a anatomia deste grupo. Assim sendo, considera-se que apenas B. humidicola apresenta a bainha parenquimática propriamente dita.

As células epidérmicas da face abaxial são poliédricas, com paredes periclinais externas recobertas por espessa cutícula (figuras 5-7), que se torna pronunciada nas porções expostas ao ambiente, assim como verificaram Wilson (1993) e Alves de Brito et al. (1997).

Brachiaria brizantha apresenta, na epiderme da face abaxial, grande quantidade de células basais de tricomas, geralmente agrupadas em conjuntos de 8-10 células, bastante desenvolvidas e salientes (figuras 5,7), assim como descrito por Thompsom \& Estes (1986). Observou-se, ainda nessa espécie, a presença de uma cavidade circular, com características secretoras (figuras 5, 7), sob a base dos tricomas. A presença dessa estrutura não é mencionada na literatura consultada e provavelmente é considerada rara em Poaceae.

Anatomia do limbo - Em secção transversal o limbo revela uma quilha, não muito pronunciada, em forma de "U" (figura 11), assim como descreveu Thompsom \& Estes (1986) e Martire \& Caldas (1986).

A superfície epidérmica da face adaxial da folha está recoberta por uma cutícula espessa (figuras 9, 10). Através do processo de dupla coloração utilizado, observou-se que a cutícula que recobre as células buliformes possui composição distinta daquela que recobre as células epidérmicas ordinárias (figuras 9,10 ). Metcalfe (1960) cita que as paredes periclinais externas das células buliformes podem estar, freqüentemente, cutinizadas e espessadas, porém não menciona diferenças na composição dos estratos cuticulares entre células epidérmicas ordinárias e as especializadas.

A epiderme da face adaxial apresenta células buliformes dispostas nas regiões intercostais. Estas células são maiores que as epidérmicas ordinárias e 


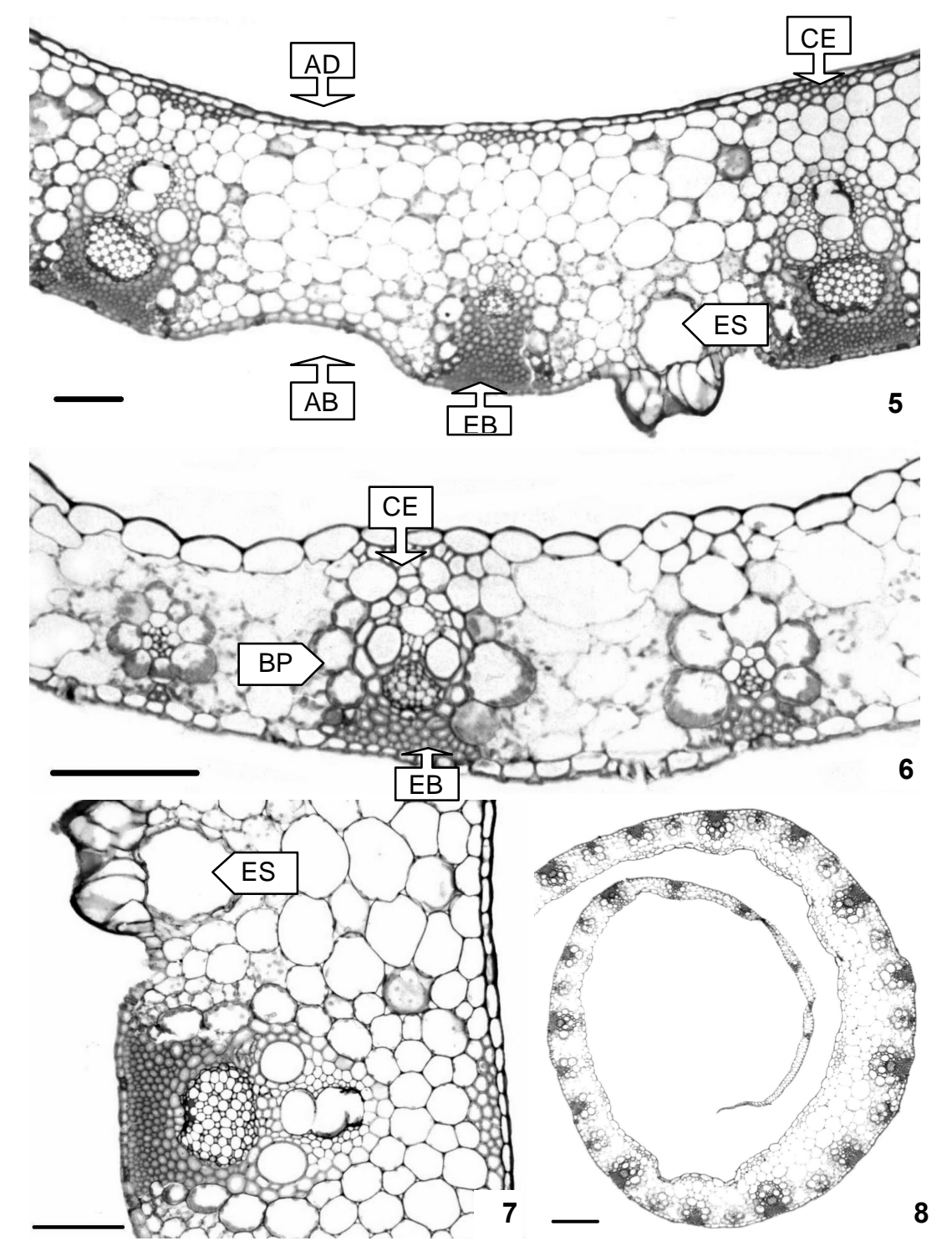

Figuras 5-8. Secções transversais da bainha foliar do estrato apical de Brachiaria. 5 e 7 - B. brizantha. 6 e 8 - B. humidicola. Barra $=90 \mu \mathrm{m}(5,6,7)$ e $180 \mu \mathrm{m}(8) . \mathrm{AB}=$ face abaxial; $\mathrm{AD}=$ face adaxial; $\mathrm{BP}=$ bainha parenquimática; $\mathrm{CE}=$ calota esclerenquimática; $\mathrm{EB}=$ extensão de bainha feixe; $\mathrm{ES}=$ estrutura secretora.

apresentam paredes delgadas, principalmente, as anticlinais (figuras 9, 10). Tais células estão relacionadas tanto com o enrolamento da folha, em situações de déficit hídrico, como com a expansão foliar a partir da gema (Fahn 1974, Mauseth 1988). Em ambas as superfícies da epiderme é possível visualizar complexos estomáticos.

O mesofilo é composto de parênquima clorofiliano, com poucos espaços intercelulares, não havendo diferenciação entre os parênquimas clorofilianos paliçádico e lacunoso, constituindo assim, o mesofilo homogêneo (figuras 9, 10).

Como amplamente descrito na literatura, as gramíneas tropicais com via fotossintética $\mathrm{C}_{4}$ apresen- tam anatomia Kranz. Nesse tipo de estrutura, as células do parênquima clorofiliano dispõem-se radialmente ao redor dos feixes. Internamente a essa coroa de células do mesofílo, encontra-se a bainha parenquimática do feixe vascular. Essa bainha, nas espécies em estudo, é simples, ou seja, apresenta apenas uma camada de células (figuras 9,10), estando de acordo com a descrição feita por Metcalfe (1960), para o gênero Brachiaria. Nas células dessa bainha nota-se grande quantidade de cristais prismáticos, assim como Martire \& Caldas (1986) observaram no mestoma de B. radicans, além dos cloroplastídios em disposição centrífuga no citoplasma (figuras 9, 10). A bainha parenquimática em $B$. humidicola apresenta células 


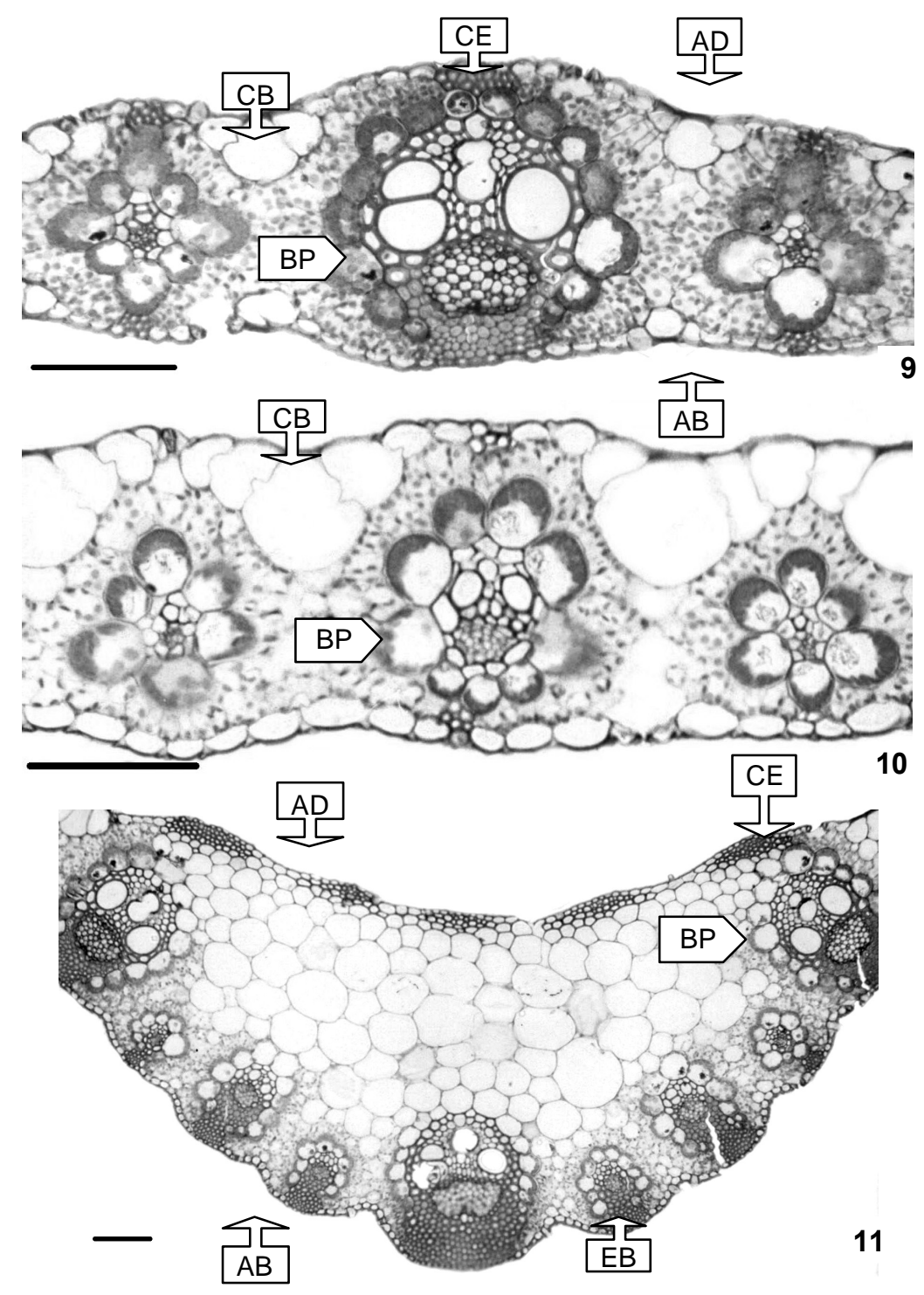

Figuras 9-11. Secções transversais da lâmina foliar do estrato basal de Brachiaria. 9 - Limbo de B. brizantha. 10 - Limbo de B. humidicola. 11- Região da quilha de B. brizantha. Barra $=90 \mu \mathrm{m}(9,10,11) . \mathrm{AB}=$ face abaxial; $\mathrm{AD}=$ face adaxial; $\mathrm{BP}=$ bainha parenquimática; $\mathrm{CB}=$ células buliformes; $\mathrm{CE}=$ calota esclerenquimática; $\mathrm{EB}=$ extensão de bainha do feixe.

mais uniformes, enquanto em $B$. brizantha essas células apresentam tamanho e formato variado.

No limbo, assim como na bainha foliar, observase a presença de feixes vasculares em três tamanhos. Os feixes maiores são de forma poligonal e, envolvendoos, encontra-se a bainha parenquimática, bastante desenvolvida, contínua e cujas células apresentam paredes ligeiramente espessadas. Nos feixes maiores encontra-se, adaxial e abaxialmente, uma calota esclerenquimática, sub-epidérmica, composta de 2-3 camadas de células (figura 9). Em $B$. brizantha observou-se que nos feixes maiores, a calota de esclerênquima da face abaxial está unida ao feixe, formando uma extensão de bainha de feixe (figura 9).
Os feixes vasculares de médio porte são circulares e, em B. brizantha, apresentam calotas esclerenquimáticas em ambas as faces (figura 9). Os feixes de pequeno porte possuem forma semelhante aos médios. Nos feixes menores, muitas vezes não é possível distinguir, com segurança, o xilema do floema, a calota esclerenquimática é bastante reduzida e apenas em $B$. brizantha pode ser observada em ambas as faces. Os feixes menores também são envoltos pela bainha parenquimática, formada de células bastante desenvolvidas.

Agradecimentos - Os autores agradecem à EPAGRI S.A. E.E.Itajaí, pelo fornecimento do material vegetal, instalação e manutenção do experimento. 


\section{Referências bibliográficas}

ALCÂNTARA, P.B. \& BUfARAH, G. 1992. Plantas forrageiras: gramíneas e leguminosas. $4^{\underline{a}}$ ed. Nobel, São Paulo.

ALVES DE BRITO, C.J.F. \& ALQUINI, Y. 1996. A new method for staining botanical material embedded in glycol methacrylate. Arquivos de Biologia e Tecnologia 39:949-951.

ALVES DE BRITO, C.J.F., RODELLA, R.A., DESCHAMPS, F.C. \& ALQUINI, Y. 1997. Organização estrutural da lâmina e bainha foliar de capim-elefante (Pennisetum purpureum Schum. - Poaceae). Arquivos de Biologia e Tecnologia 40:662-672.

BUVAT, R. 1989. Ontogeny, cell differentiation and structure of vascular plants. Springer-Verlag, Berlin.

ESAU, K. 1974. Anatomia das plantas com sementes. Edgard Blücher, São Paulo.

ESAU, K. 1972. Anatomia vegetal. $2^{\underline{a}}$ ed. Omega, Barcelona. FAHN, A. 1974. Anatomia vegetal. $2^{\underline{a}}$ ed. H. Blume, Madrid. FEDER, N. \& O'BRIEN, T.P. 1968. Plant microtechnique: some principles and new methods. American Journal of Botany 55:123-142.

HAYWARD, H. 1953. Estructura de las plantas utiles. Acme, Buenos Aires.

JOHANSEN, D.A. 1940. Plant microtechnique. McGraw-Hill Book Co., New York.

MARTIRE, G. \& CALDAS, L.Q.A. 1986. Morfologia interna do colmo e das folhas de Brachiaria radicans Napper. Ciência Prática 10:235-240.

MAUSETH, J.D. 1988. Plant anatomy. Benjamin/Cummings Publishing, Menlo Park.

MAUSETH, J.D. 1995. Botany: an introduction to plant biology. $2^{\text {nd }}$ ed Saunders College Publishing, Chicago.
METCALFE, C.R. 1960. Anatomy of monocotyledons. Gramineae. Clarendon Press, Oxford, v.1.

MILBY, T.H. 1971. The leaf anatomy of buffalo grass, Buchloë dactyloides (Nutt.) Engelm. Botanical Gazette 132:308-313.

OLIVEIRA, B.A.D. de, FARIA, P.R.S., SOUTO, S.M., CARNEIRO, A.M., DÖBEREINER, J. \& ARONOVICH, S. 1973. Identificação de gramíneas tropicais com via fotossintética $\mathrm{C}_{4}$ pela anatomia foliar. Pesquisa Agropecuária Brasileira 8:267-271.

PUPO, N.I.H. 1980. Manual de pastagens e forrageiras. Instituto Agronômico de Campinas, Campinas.

RODELLA, R.A., ISHIY, C.M., MAIMONI-RODELLA, R.C.S. \& AMARAL JÚNIOR, A. 1982. Estudo quantitativo de características anatômicas de folhas de duas espécies de Brachiaria. Revista Agrociência 2:21-30.

SALERNO, A.R., VETTERLE, C.P., DESCHAMPS, F.C. \& FREITAS, E.A.G. 1990. Gramíneas forrageiras estivais perenes no Baixo Vale do Itajaí. Boletim Técnico n. 49. Empresa de Pesquisa Agropecuária de Santa Catarina, Florianópolis.

SMITH, L.B., WASSHAUSEN, D.C. \& KLEIN, R.M. 1982. Gramíneas. In Flora ilustrada catarinense, parte 1. Herbário Barbosa Rodrigues, Itajaí.

THOMPSON, R.A. \& ESTES, J.R. 1986. Anthecial and foliar micromorphology and foliar anatomy of Brachiaria (Poaceae: Paniceae). American Journal of Botany 73:398-408.

WILSON, J.R. 1993. Organization of forage plant tissues. In Forage cell wall structure and digestibility. (H.G. Jung, D.R. Buxton, R.D. Hatfield \& J. Ralph, eds.). American Society of Agronomy, Wisconsin, p.1-32. 